\title{
Pancreatic islet cell tumour with watery diarrhoea and hypokalaemia
}

\author{
D. J. STOKER ${ }^{1}$ AND V. WYNN \\ From St Mary's Hospital, London
}

SUMMARY A further patient with watery diarrhoea and hypokalaemia in association with a non-beta islet cell tumour of the pancreas is reported. The mechanism by which fluid and electrolyte losses are produced is discussed and cases previously reported are reviewed.

Diarrhoea in association with a non-specific islet cell tumour of the pancreas was first reported in 1947 by Gordon and Olivetti. In 1955, Zollinger and Ellison described a syndrome of recurrent peptic ulceration and gastric hypersecretion in patients with non-beta cell tumours of the pancreas. In one of their patients (case 1) diarrhoea preceded the other symptoms by eight years. By 1964 Ellison and Wilson had collected 260 cases of non-specific islet cell tumour of the pancreas, of which 190 had been reported in the literature. Ellison and Wilson (1964) regarded all these cases as examples of the Zollinger-Ellison syndrome and described their symptomatology. Peptic ulceration occurred in $93 \%$ and diarrhoea in $36 \%$. About $18 \%$ of the patients had significant hypokalaemia (serum potassium below 2.9 m-equiv/l). Seven per cent of the patients had diarrhoea without peptic ulceration. The demonstration by Gregory and his colleagues (Gregory, Tracy, French, and Sircus, 1960; Gregory and Tracy, 1964) of gastrin in extracts from primary and secondary tumours verified the original postulate of Zollinger and Ellison that a humoral substance was responsible for the clinical picture, by stimulation of gastric secretion.

Recently it has become apparent that a syndrome of intractable watery diarrhoea with hypokalaemia can be caused by a non-specific islet cell tumour presumably due to the elaboration of a humoral substance, other than gastrin, causing enhanced loss of intestinal secretions (Verner and Morrison, 1958; Espiner and Beaven, Received for publication 18 June 1970. 'Present address: St George's Hospital, London SW1
1962). Gastric hypersecretion and peptic ulceration is not part of this syndrome. We therefore feel that, since the pathogenesis of the two conditions is different, these patients should not be regarded as examples of the Zollinger-Ellison syndrome as has been done by Ellison and Wilson (1964) in their collection of cases. We do not agree with Marks, Bank, and Louw (1967) that the syndrome should also require gastric hypochlorhydria or achlorhydria as this proviso further subdivides the syndrome in an unwarranted manner. It may be that reduced gastric acid secretion occurs eventually in all patients, but certainly in a number of reported cases, gastric secretion was normal at the time of presentation.

In addition a number of other features, present only in a proportion of the patients, have been described. These include hypercalcaemia (Brown and Crile, 1964; Kofstad, Frøyshov, Gjone, and Blix, 1967), skin manifestations (Martini, Strohmeyer, Haug, and Gusek, 1964), and hyperglycaemia (von Knappe, Flemming, Stobbe, and Wendt, 1966). The confusing situation has arisen where one group of authors names the condition Verner-Morrison syndrome (Pabst, Kümmerle, Hennekedser, and Mappes, 1969) whilst another (Goulon, Rapin, Charleux, Baguet, Kuntziger, Nouailhat, Bardis, and Breteau, 1966) excludes the Verner-Morrison patient from the syndrome. We therefore feel that until the syndrome can be defined in clear aetiological and pathological terms, it should include watery diarrhoea leading to hypokalaemia in a patient with a nonspecific islet cell tumour of the pancreas, who does 
not have gastric hypersecretion or peptic ulceration of the small intestine.

The clarification of this syndrome has been brought nearer by the recent extraction from tumours in two patients of substances with secretin-like effects (Zollinger, Tompkins, Amerson, Endahl, Kraft, and Moore, 1968). So far a suitable name to describe this syndrome has not been generally accepted.

This paper describes such a syndrome occurring in a woman of 61 years, with observations on the nature of the faecal electrolyte losses. Twenty-six similar cases in the literature are reviewed.

\section{Case Report}

A 61-year-old woman developed aching of thighs and shoulders towards the end of April 1964. The condition progressed over a period of five days to weakness of the neck muscles, stiffness of the upper limbs with carpal spasm, and complete paralysis of the lower limbs. She was admitted to hospital in France, where she was on holiday, and was found to have a plasma potassium level below 2.0 m-equiv/l. Clinical improvement followed intravenous administration of potassium salts and she returned to England, being admitted to hospital on 7 May, when the plasma potassium level was $1.6 \mathrm{~m}$-equiv/litre.

In May 1963, over the space of a few hours, she began to have a watery diarrhoea, passing three to seven fluid stools daily, without pain or rectal bleeding. Investigation at that time, which included both barium meal and barium enema, did not reveal any cause for the diarrhoea, which persisted up to the time of her present admission to hospital. Earlier, bowel function had been normal.

\section{AT ADMISsIon}

Examination on admission to St Mary's Hospital on 12 May showed a rather dehydrated, slightly obese woman, with some abdominal distension. Blood pressure was $130 / 70 \mathrm{~mm} \mathrm{Hg}$, and, apart from reduced power in the proximal muscles of the lower limbs, there were no abnormal physical signs and latent tetany was not demonstrable. Sigmoidoscopy showed a normal if rather pale mucosa, and the rectum contained a quantity of fluid with the appearance of urine. No pathogens were present on culture. Electrocardiograms were compatible with hypokalaemia.

\section{Haematology}

Routine haematological examination showed only haemoconcentration, the haemoglobin being $18.6 \mathrm{~g} / 100 \mathrm{ml}$ and the packed cell volume $55 / 100$ $\mathrm{ml}$. Subsequent investigations showed the haemoglobin to vary between 12.6 and $14.5 \mathrm{~g} / 100 \mathrm{ml}$. The blood film showed no abnormality.
Biochemistry

Plasma electrolytes on admission were: $\mathrm{Na} 141$ m-equiv/l, K 2.7 m-equiv/l, Cl 97 m-equiv/l, T. $\mathrm{CO}_{2} 21 \mathrm{~m}$ moles/l. Subsequent estimations of plasma potassium before laparotomy gave levels of $2 \cdot 8,3 \cdot 9,3 \cdot 1$, and $3 \cdot 1 \mathrm{~m}$-equiv/l. Blood urea was $86 \mathrm{mg} / 100 \mathrm{ml}$ falling to a preoperative level of $48 \mathrm{mg} / 100 \mathrm{ml}$. Serum calcium was $9.6 \mathrm{mg} / 100 \mathrm{ml}$ and repeated values were also normal. Tests of liver function were normal, with bilirubin 0.8 $\mathrm{mg} / 100 \mathrm{ml}$, alkaline phosphatase $9.5 \mathrm{KA}$ units, plasma proteins $7 \cdot 1 \mathrm{~g} / 100 \mathrm{ml}$ (albumin $4 \cdot 1 \mathrm{~g}$ and globulin $3.0 \mathrm{~g} / 100 \mathrm{ml}$ ), SGOT 16 and SGPT 40 SF units. Fasting blood sugar was $110 \mathrm{mg} / 100 \mathrm{ml}$. The urine sodium and potassium excretion was low (about $10 \mathrm{~m}$-equiv/l per day for each cation) unless the body deficits of these ions was made good by massive intravenous infusions. The faecal excretion of sodium, potassium, chloride, and bicarbonate was extremely large, and is the subject of later discussion.

\section{Gastric function}

Overnight gastric secretion totalled $142 \mathrm{ml}$ with free $\mathrm{HCl} 100 \mathrm{~m}$-equiv/l and $p \mathrm{H} 1 \cdot 1$. An augmented histamine test meal produced a total of $217 \mathrm{ml}$ gastric juice in one hour. The estimation of $\mathrm{H}^{+}$ ion content was unfortunately omitted, but in terms of volume the result does not indicate hypersecretion.

\section{Radiology}

Chest radiograph showed a raised right dome of the diaphragm which, however, moved satisfactorily on respiration. A barium meal revealed a small hiatus hernia, an otherwise normal stomach and coarse duodenal mucosa. The small bowel pattern was grossly abnormal and irregular, and showed both segmentation and flocculation of barium, most marked in the ileum. Barium passed rapidly through the small bowel to enter the colon within one and a half hours. Barium in the large bowel was greatly diluted by fluid, but no other abnormality was apparent.

\section{Progress}

Preoperative management was characterized by a continuous struggle to replace the large fluid and electrolyte losses in the stools, the volume of which was as high as $9 \cdot 21 / 24$ hours, and on one occasion contained $453 \mathrm{~m}$-equiv of potassium in 24 hours. Details are shown in Figure 1. The quantity of potassium administered intravenously was usually over 200 m-equiv/24 hours and sometimes over twice this amount. In the absence of a demonstrable local cause for the diarrhoea, a diagnosis of pancreatic islet cell tumour was made, and laparotomy was performed on 27 May 1964.

\section{Laparotomy}

The entire gut was atonic and distended with fluid. The pancreas was slightly enlarged and $?$ 
on the anterior surface of its head were two tumours each $1.5 \mathrm{~cm}$ in diameter. The first was removed easily by blunt dissection but the second separated only with difficulty. No other abnormality was seen in the abdomen.

\section{Histology}

Both tumours were islet cell tumours. The first tumour showed uniform structure and was surrounded with a thin rim of lymphoid tissue, which suggested it could be a secondary deposit replacing a lymph node. The second tumour was encapsulated, arising in pancreatic tissue. Its structure showed all the variations reported in islet cell tumours. Nuclear size was variable and there was infiltration of the capsule. The tumour was considered potentially malignant and probably not completely removed.

\section{AFTER OPERATION}

Following operation there was only a temporary reduction in faecal volume lasting 24 hours and probably due to paralytic ileus. Thereafter stool volume returned to the preoperative level and it was decided that only removal of the whole

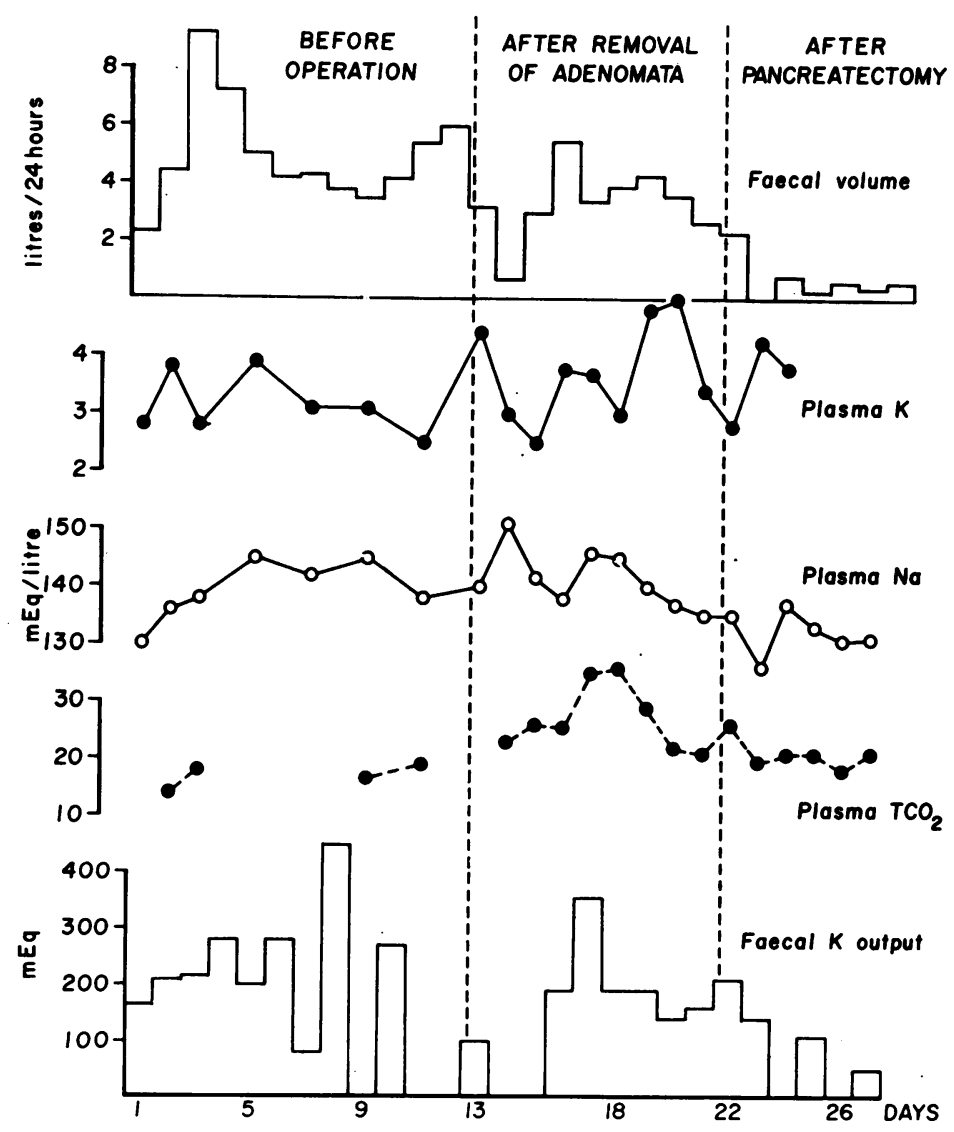

Fig. 1 Condition before treatment and the effect of resection of adenomata and pancreatectomy on the fluid and electrolyte levels. pancreas could effect a cure. On 5 May total pancreatectomy was performed. The duodenum, part of the stomach, and the spleen were removed. The gastric remnant was anastomosed to the side of the proximal jejunum. The gallbladder contained numerous stones and was removed, the common bile duct being inserted into the blind end of the jejunum.

\section{Histology}

The pancreas showed proliferation of the terminal ducts so that the centres of many acini were filled with cells having a clear cytoplasm. This change was most marked in the head, adjacent to the tumour site, where the clear cells formed small nodules. These cells resembled those in the removed tumours and a few contained granules (probably beta granules). The pancreatic islets were probably normal, a few were enlarged and some showed duct formation. In parts of the gland the acini were proliferating and special stains showed tumour cells in veins. A biopsy of jejunum taken at operation was normal with normal numbers of Paneth cells.

\section{POSTOPERATIVE COURSE}

The patient's immediate progress after the operation was good and there was a dramatic fall in the volume of faecal fluid, which never thereafter reached its earlier levels or potassium content (Fig. 1). Without potassium supplements, however, in a fortnight the plasma potassium was $2.0 \mathrm{~m}$-equiv $/ 1$ and faecal volumes were of the order of 1.0-2.0 1/24 hours, often containing 100200 m-equiv potassium. Pancreatic extracts ${ }^{1}$ had been given since pancreatomy. Throughout her illness in hospital she had been noted to have intermittent attacks of flushing of the face, neck, and upper chest. During July she was greatly troubled by dysphagia and choking attacks triggered off by drinking. A thick barium swallow showed narrowing of the lowermost oesophagus, confirmed by oesophagoscopy, and relieved completely by the passage of bougies. In September a transient jaundice resulted from bile duct obstruction and late in the month the volume of watery stool increased. It was felt that with the possibility that this was due to residual tumour tissue, the effect of corticosteroids should be tried. She began with prednisolone, $40 \mathrm{mg}$ daily, receiving neomycin at the same time as pyrexia had persisted since the appearance of jaundice. Marked reduction of diarrhoea resulted and it was the impression over the next few months that both antibiotics and prednisolone had a beneficial effect on the diarrhoea, so that in December she produced formed stools for the first time. An intermittently discharging faecal fistula in October failed to heal completely and in February 1965 further laparotomy revealed a blind loop of jejunum caused by adhesion of the 'Panar granules from the Armour Pharmaceutical Company. 
bowel to an abscess cavity behind the stomach remnant. The abscess was drained and necrotic bowel resected. No evidence of tumour recurrence or metastasis was found at this operation.

On 27 April 1965, she again developed diarrhoea and became stuporous with a plasma potassium level of $1.7 \mathrm{~m}$-equiv/l and blood sugar of $675 \mathrm{mg} / 100 \mathrm{ml}$. She was given intravenous fluid and electrolyte replacement, but developed thromboses in the right femoral and popliteal arteries necessitating an above-knee amputation of the right lower limb on 15 May. On 12 October, the left foot became gangrenous with the result that a mid-thigh amputation had to be performed on 30 October. At this time she was passing about four to five watery stools a day. The administration of 16 units of ACTH daily controlled the diarrhoea and she was again discharged from hospital on 18 December, receiving 12 units of ACTH daily.

She remained well until the end of March 1966 when diarrhoea recurred but was controlled by increased doses of ACTH. Thereafter diarrhoea was abolished by doses of between 40 and 60 units a day, reverting afterwards to smaller maintenance doses. Other symptoms at this time were backache resulting from osteoporosis, and mental depression.

In August 1966 she developed pitting oedema which, at first, responded to diuretics, but subsequently she became restless and disorientated with intermittent vomiting. On 1 September she was admitted to hospital in coma. She made an initial improvement, then became jaundiced and more confused. Hepatic failure supervened and she died on 9 September 1966.

\section{NECROPSY}

At necropsy the liver was found to be shrunken, pale yellow in colour, and scattered with minute dark red areas. It contained five secondary deposits of pancreatic islet cell carcinoma, the largest of which was $2 \mathrm{~cm}$ in diameter. A collection of pus was present under the left diaphragm.

\section{Histology}

The appearance of the tumour was much the same as at the time of biopsy. The kidney showed severe hypertensive vascular disease with atrophy of some of the glomeruli and tubules with focal areas of tubular necrosis. The liver showed severe centrilobular congestion.

A metastatic nodule was deep-frozen and sent to Professor Gregory, who was unable to demonstrate any activity. In view of the fact that it was necropsy material, this result is quite inconclusive.

OBSERVATIONS ON FAECAL FLUID AND ELECTROLYTE LOSSES

During the period before operation, when the only treatment given was fluid and electrolyte replacement, the diarrhoeal fluid resembled urine in appearance. Although there was a tendency for $\Omega$ the faecal volume to be lower when the patient? was hydrated, we were not able to show a direct $\vec{F}$ quantitative relationship between the adminis- $\stackrel{\sim}{\rightarrow}$ tration of intravenous saline solution and the increase in diarrhoea, as had been shown by $\frac{\bar{c}}{\bar{c}}$.

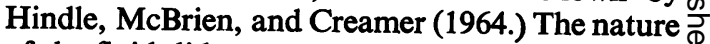
of the fluid did not suggest any degree of inflam- $\bigcirc$ matory exudation from the bowel wall in that $\%$ microscopy showed no blood or pus cells and the $\vec{\circ}$ protein content as measured by trichloracetic acid $\rightarrow$ precipitation was negligible. Although the daily $\vec{\omega}$ volume of diarrhoeal fluid varied between 2 and $9 \stackrel{\curvearrowright}{ }$ litres before pancreatectomy, this need not reflect $\risingdotseq$ the daily production of fluid because of pooling $\overrightarrow{ }$ of fluid in the dilated gut. The faecal fluid was alkaline, the $p \mathrm{H}$ varying from $7 \cdot 24$ to $8 \cdot 35$, with $\overrightarrow{0}$

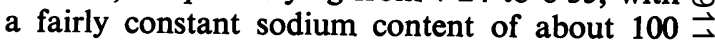
m-equiv/litre. The potassium concentration was 을 rather more variable and tended to vary inversely $\rightarrow$ with the volume of faeces. Despite this tendency, $z$ however, a greater 24-hour loss of potassium occurred when there was a greater faecal fluid loss (Fig. 1). The total cation concentration $\left(\mathrm{Na}^{+}+\mathrm{K}^{+}\right)$of the fluid tended to be constant and is shown by the linear relation between faecal volume and the combined sodium and potassium losses (Fig. 2). Table I shows that there is a clear difference in the electrolytic composition between the duodenal contents and the faeces, and this results from an exchange of sodium and chloride for potassium and bicarbonate during the passage through the gut. The sodium concentration of the duodenal contents is probably rather high (Thaysen, 1960) and the defect in our patient could be due to a failure of sodium absorption in the small intestine. This is discussed below.

\begin{tabular}{lll}
\hline & Duodenum & Faeces \\
\hline$p \mathrm{H}$ & $8 \cdot 1$ & $8 \cdot 1$ \\
$\mathrm{TCO} 2$ & $18 \cdot 0 \mathrm{mM} / 1$ & $47 \cdot 1 \mathrm{mM} / 1$ \\
$\mathrm{Na}$ & $154 \mathrm{~m}$-equiv/1 & $120 \mathrm{~m}$-equiv/1 \\
$\mathrm{K}$ & $3 \cdot 0 \mathrm{~m}$-equiv/1 & $29 \mathrm{~m}$-equiv/1 \\
$\mathrm{Cl}$ & $124 \mathrm{~m}$-equiv/1 & $97 \mathrm{~m}$-equiv $/ 1$ \\
Amylase & 2,080 Somogyi units & \\
\hline
\end{tabular}

Table I Analysis of bowel contents at time of pancreatectomy

\section{Discussion}

Profuse watery diarrhoea, without the passage of blood or pus and often without pain, yet proceeding to water and electrolyte depletion, is not common. Investigations must aim at excluding, by history and observation, over-purgation (Schwartz and Relman, 1953), and by barium radiology and sigmoidoscopy the presence of a villous tumour of the colon. In the absence of such conditions an islet cell tumour of the 
pancreas should be suspected. A total of 27 cases, including the one reported in this paper, characterized by profuse watery diarrhoea, hypokalaemia, and islet cell tumour, without either gastric hypersecretion or peptic ulceration, are detailed in Table II. The age of incidence ranges from 19 to 67 years, with a preponderance of females $(2: 1)$. The duration of diarrhoea before definitive diagnosis, usually at operation or necropsy, varied from 11 months to 14 years, with an average of $2 \cdot 3$ years. Six patients had a malabsorption pattern on barium radiographs, and although this is probably a reflection of hypersecretion and hypermotility of the intestine (Weber, Lewis, and Heasley, 1959) rather than malabsorption (steatorrhea was not demonstrated in these patients) the appearances were not directly related to faecal volume. Nine patients showed dilatation of some part of the intestine. Most patients had gastric secretion which was within normal limits, but seven had achlorhydria and two hypochlor- hydria. These findings are in direct contrast to the Zollinger-Ellison syndrome, as originally described, where all affected must by definition have hyperacidity or peptic ulceration. When all patients with islet tumours are considered, 94\% are seen to have hyperacidity and $93 \%$ peptic ulceration (Ellison and Wilson, 1964). As previously indicated, diarrhoea is a symptom in about $30 \%$ of cases of the Zollinger-Ellison syndrome, but it is rarely of the profuse choleraic type described here. It should be admitted that two reported cases of the Zollinger-Ellison syndrome with peptic ulceration (Moldawer et al, 1954; Morrison, Rawson, and Fitts, 1962), and one with hyperchlorhydria alone (Goulon, Mercier, Reilly, and Laporte, 1960) had profuse diarrhoea leading to hypokalaemia. Therefore there is a small degree of overlap between these symptom complexes and possibly a tumour may elaborate more than one secretagogue hormone (Verner and Morrison, 1958). This provision aside, there is a clear
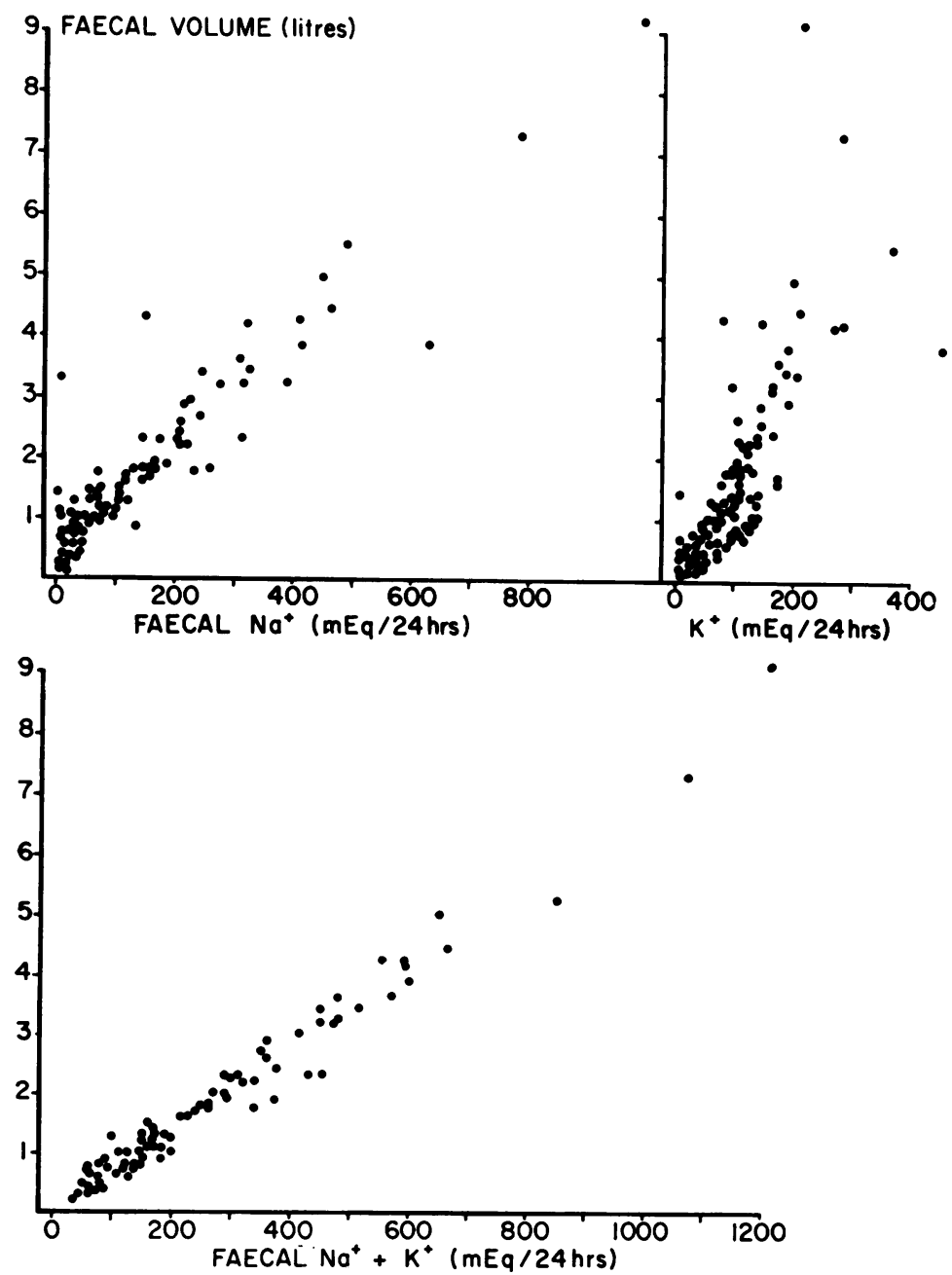

Fig. 2 Relationship of stool volume to its fluid and electrolyte content. 
distinction of syndromes coupled with an histologically identical tumour.

The maximal faecal fluid loss of the patient reported here was $\mathbf{9 \cdot 2}$ litres, one of the highest recorded, whilst the maximal faecal potassium loss of 453 m-equiv in 24 hours is the highest recorded. It is clear that in the cases described earlier that the magnitude of the electrolyte loss was not appreciated and the first four patients reported died of hypokalaemia (Table II). Some degree of metabolic acidosis results from bicarbonate loss in the stools (Marks et al, 1967) but this is helped by potassium replacement. The relief of the diarrhoea following the removal of pancreatic neoplastic tissue in the present patient has been described before (Chears et al, 1961; Murray et al, 1961; Thompson, 1962; Brown and Crile, 1964; Matsumoto et al, 1966). Tetany has not been a frequent feature of the syndrome, but was discussed by Verner and Morrison (1958), who thought that it might be due to correction of potassium deficiency and acidosis (Fourman and McCance, 1955). In the present case tetany preceded any therapy, and in the presence of a normal calcium level in the blood, may have been related to severe hypokalaemia (Marks et al, 1967) or to a low plasma magnesium level in the early part of her hospital admission.
An interesting feature recorded in our patient was the occurrence of intermittent flushing of the face and neck. The patients of Murray et al (1961) and Matsumoto et al (1966) complained of occasional flushing sensations about the face and neck lasting for several minutes at a time but without discernible reddening of the skin. The occurrence of flushing in a syndrome associated with diarrhoea must lead to comparisons with the carcinoid syndrome. However, in all three patients the urinary 5-hydroxindoleacetic acid excretion was normal and the character of the flushing was unlike that seen in patients with carcinoid metastases. The cause of flushing in the carcinoid syndrome is, as yet, unknown, and no hormone has been found to produce both flushing and diarrhoea. Robertson, Peart, and Andrews (1962) consider the release of serotonin into the general circulation to be an unlikely cause. In the comparison of these two conditions it is interesting that Williams and Sandler (1963) have drawn attention to the confusion that may arise on histological grounds between carcinoid and isletcell tumours, particularly when the carcinoid tissue does not exhibit the characteristic staining reactions. The skin condition in the case reported by Martini et al (1964) seems to be unique.

\begin{tabular}{|c|c|c|c|c|c|c|}
\hline Author(s) & Age & $\operatorname{Sex}$ & $\begin{array}{l}\text { Duration of } \\
\text { Diarrhoea }\end{array}$ & $\begin{array}{l}\text { Lowest Plasma } K \\
(m-e q u i v / l)\end{array}$ & Barium radiograph & Peptic Ulceration \\
\hline $\begin{array}{l}\text { Moldawer, Nardi, and Raker (1954) } \\
\text { Priest and Alexander (1957) }\end{array}$ & $\begin{array}{l}57 \\
56\end{array}$ & $\underset{\mathbf{F}}{\mathbf{F}}$ & $\begin{array}{l}5 \text { years } \\
1 \text { year }\end{array}$ & $1 \cdot 8$ & $\begin{array}{l}\text { Duodenal dilatation } \\
\text { NAD }\end{array}$ & $\begin{array}{l}\text { Present } \\
\text { Absent before therapy }\end{array}$ \\
\hline $\begin{array}{l}\text { Verner and Morrison (1958) } \\
\text { Verner and Morrison (1958) } \\
\text { Charles and Cochrane (1960) } \\
\text { Chears, Thompson, Hutcheson, } \\
\text { and Patterson (1960) } \\
\text { Parkins (1961) } \\
\text { Murray, Paton, and Pope (1961) } \\
\text { Telling and Smiddy (1961) } \\
\text { Espiner and Beaven (1962) } \\
\text { Edmeads, Matthews, McPhedran, } \\
\text { and Ezrin (1962) }\end{array}$ & $\begin{array}{l}60 \\
19 \\
49 \\
55 \\
49\end{array}$ & $\begin{array}{l}\mathbf{F} \\
\mathbf{F} \\
\mathbf{M} \\
\mathbf{F} \\
\mathbf{F}\end{array}$ & $\begin{array}{l}10 \text { months } \\
3 \text { years } \\
2 \text { years } \\
1 \text { year } \\
5 \text { years } \\
14 \text { years } \\
6 \text { months } \\
1 \text { year } \\
1 \text { year }\end{array}$ & $\begin{array}{l}2 \cdot 6 \\
1 \cdot 8 \\
1 \cdot 2 \\
1 \cdot 8 \\
2 \cdot 1 \\
2 \cdot 6 \\
2 \cdot 2 \\
1 \cdot 5 \\
1 \cdot 9\end{array}$ & $\begin{array}{l}\text { NAD } \\
\text { NAD } \\
\text { NAD } \\
\text { Duodenal dilatation } \\
\text { Small intestine dilatation } \\
\text { NAD } \\
\text { Sprue pattern } \\
\text { Dilated colon } \\
\text { NAD }\end{array}$ & $\begin{array}{l}\text { Absent } \\
\text { Absent } \\
\text { Absent } \\
\text { Absent } \\
\text { Absent } \\
\text { Absent } \\
\text { Absent } \\
\text { Absent } \\
\text { Absent }\end{array}$ \\
\hline $\begin{array}{l}\text { Thompson (1962) } \\
\text { Hindle et al (1964) } \\
\text { Deleu, Tytgat, and van Goidsen- } \\
\text { hoven (1964) } \\
\text { Brown and Crile (1964) } \\
\text { Longmire (1964) } \\
\text { Martini et al (1964) }\end{array}$ & $\begin{array}{l}60 \\
29 \\
\\
59 \\
34 \\
50 \\
29\end{array}$ & $\begin{array}{l}\mathbf{M} \\
\mathbf{M} \\
\mathbf{F} \\
\mathbf{M}\end{array}$ & $\begin{array}{l}1 \frac{1}{2} \text { years } \\
11 \text { months } \\
4 \text { years } \\
10 \text { months } \\
3 \text { years } \\
4 \text { months }\end{array}$ & $\begin{array}{l}\text { 'low' } \\
2.9 \\
1.6 \\
<2 \cdot 0 \\
1.8 \\
1.8\end{array}$ & $\begin{array}{l}\text { NAD } \\
\text { Intestinal dilatation } \\
\text { Duodenal filling } \\
\text { Deformed cap, wide duodenum, } \\
\text { sprue pattern }\end{array}$ & $\begin{array}{l}\text { Absent } \\
\text { Absent } \\
\text { Absent } \\
\text { Absent } \\
\text { Absent } \\
\text { Absent }\end{array}$ \\
\hline $\begin{array}{l}\text { Goulon et al }(1966) \\
\text { Knappe et al }(1966) \\
\text { Matsumoto, Peter, Schultze, Hakim, } \\
\quad \text { and Franck (1966) } \\
\text { Kofstad et al (1967) } \\
\text { Marks et al (1967) }\end{array}$ & $\begin{array}{l}64 \\
38 \\
49 \\
46 \\
34\end{array}$ & $\begin{array}{l}\mathbf{F} \\
\mathbf{F} \\
\mathbf{F} \\
\mathbf{M} \\
\mathbf{M}\end{array}$ & $\begin{array}{l}14 \text { months } \\
5 \text { months } \\
3 \frac{1}{2} \text { years } \\
10 \text { months } \\
1 \text { year }\end{array}$ & $\begin{array}{l}2 \cdot 5 \\
1 \cdot 8 \\
2 \cdot 2 \\
2 \cdot 8 \\
2 \cdot 3\end{array}$ & $\begin{array}{l}\text { NAD } \\
\text { NAD } \\
\text { NAD } \\
\text { NAD } \\
\text { Prominent small bowel mucosal } \\
\quad \text { pattern with clumping in } \\
\text { terminal ileum }\end{array}$ & $\begin{array}{l}\text { Absent } \\
\text { Absent } \\
\text { Absent } \\
\text { Absent } \\
\text { Absent before therapy }\end{array}$ \\
\hline $\begin{array}{l}\text { Glober (1968) } \\
\text { Hess (1968) } \\
\text { Zollinger et al (1968) }\end{array}$ & $\begin{array}{l}49 \\
57 \\
24\end{array}$ & $\begin{array}{l}\mathbf{F} \\
\mathbf{F} \\
\mathbf{F}\end{array}$ & $\frac{6 \text { years }}{4 \text { years }}$ & $\frac{2 \cdot 2}{1 \cdot 6}$ & $\begin{array}{l}\text { Duodenal indentation } \\
\text { Not recorded } \\
\text { Antral indentation, dilated } \\
\text { jejunum }\end{array}$ & $\begin{array}{l}\text { Absent } \\
\text { Absent } \\
\text { Absent }\end{array}$ \\
\hline $\begin{array}{l}\text { Zollinger et al }(1968) \\
\text { Present case }\end{array}$ & $\begin{array}{l}47 \\
61\end{array}$ & $\begin{array}{l}\mathbf{F} \\
\mathbf{F}\end{array}$ & $\begin{array}{l}1 \text { year } 10 \text { months } \\
1 \text { year }\end{array}$ & $\begin{array}{l}1 \cdot 9 \\
1.6\end{array}$ & $\begin{array}{l}\text { Sprue pattern } \\
\text { Sprue pattern and small } \\
\text { intestine dilatation }\end{array}$ & $\begin{array}{l}\text { Absent } \\
\text { Absent }\end{array}$ \\
\hline
\end{tabular}


NATURE OF THE DIARRHOEAL FLUID

The recent report by Zollinger (Zollinger et al, 1968) of two patients with this syndrome seems to have solved the question of a humoral secretion producing the syndrome. A secretin-like pancreatic response was obtained in dogs from the administration of extracts of metastatic tissue from the liver. The further demonstration (Tompkins, Kraft, and Zollinger, 1969) that intravenous injection of tumour extracts, as well as synthetic and pure secretin, produces a dilute bile containing increased concentrations of chloride and bicarbonate, could explain the continuation of the diarrhoea in our patient after total pancreatectomy.

The intravenous infusion of secretin in man (Wormsley, 1968) is associated uncommonly with explosive diarrhoea. The main electrolyte responses to secretin have been shown to be: (1) a maximal bicarbonate excretion in most subjects with a fall in bicarbonate concentration in response to an increased volume of duodenal aspirate through an indwelling tube; (2) chloride concentration linearly related to the volume of duodenal aspirate; (3) unchanging concentration of both sodium and potassium, so that the output in the aspirate is linearly related to the volume.

In essence, Zollinger's recent cases (Zollinger et al, 1968) have shown that the effect of the secretin-like hormone is to introduce into the duodenum, via the bile and pancreatic juice, increased amounts of fluid rich in chloride and bicarbonate. What is not yet clear is how, in its further passage through the intestines, there is loss of normal water conservation together with electrolyte loss, the potassium loss being of greatest clinical significance.

The results in our patient (Table I) show that the sodium and chloride content of the bowel fluid decreased, while that of potassium and bicarbonate increased, during the passage through the intestine. There is little evidence that a humoral mechanism exists for secretion from the wall of the small intestine. Gregory (1962) believes that the traditional view that the succus constitutes an important digestive secretion is no longer tenable in the light of the accumulated evidence. Pure succus entericus contains no digestive enzymes except enterokinase and amylase, the numerous other enzymes being of intracellular origin and derived from the considerable desquamation of epithelial cells. Nevertheless, although no discrete secretory process is present, there is a simultaneous bi-directional flow of water and electrolytes between blood and gut lumen (Visscher, Varco, Carr, Dean, and

\begin{tabular}{|c|c|c|c|c|c|}
\hline Gastric Secretion & Pancreatic Tumour & $\begin{array}{l}\text { Maximum Faecal } \\
\text { Vol/24 hours }(l)\end{array}$ & $\begin{array}{l}\text { Maximum } K \text { Loss } \\
\text { in Faeces per } 24 \\
\text { hours (m-equiv) }\end{array}$ & $\begin{array}{l}\text { Carbohydrate } \\
\text { Metabolism }\end{array}$ & Result \\
\hline $\begin{array}{l}\text { Normal } \\
\text { Normal }\end{array}$ & $\begin{array}{l}\text { Adenoma } \\
\text { Multiple adenomas }\end{array}$ & $\begin{array}{l}\overline{6-7 \cdot 1} \text { (urine and } \\
\text { faeces) }\end{array}$ & $\overline{74}$ & $\overline{-}$ & $\begin{array}{l}\text { Died: probably hypokalaemia } \\
\text { Died: amputation and hypokalaemia }\end{array}$ \\
\hline $\begin{array}{l}\text { Normal } \\
\text { Normal } \\
-\end{array}$ & $\begin{array}{l}\text { Adenoma and hyperplasia } \\
\text { Adenoma } \\
\text { Carcinoma }\end{array}$ & 二 & $\overline{\overline{111}}$ & $\begin{array}{l}\text { Normal } \\
\text { Normal } \\
\text { Diabetic OGTT }\end{array}$ & $\begin{array}{l}\text { Died: hypokalaemia } \\
\text { Died: hypokalaemia } \\
\text { Died: hypokalaemia }\end{array}$ \\
\hline $\begin{array}{l}\text { Normal } \\
\text { Normal } \\
\text { Achlorhydria } \\
\overline{\text { Achlorhydria }}\end{array}$ & $\begin{array}{l}\text { Adenoma } \\
\text { Adenoma } \\
\text { Adenoma } \\
\text { Carcinoma } \\
\text { Carcinoma }\end{array}$ & $\begin{array}{l}-3.1 \\
7.8 \\
6.9 \\
3.5\end{array}$ & $\overline{\bar{z}}$ & $\begin{array}{l}\text { Diabetic } \\
\text { Normal } \\
\overline{\text { Diabetic }} \\
\text { Diabetic OGTT }\end{array}$ & $\begin{array}{l}\text { Survived } \\
\text { Died: peritonitis } \\
\text { Survived } \\
\text { Died: hypokalaemia } \\
\text { Survived (liver metastases) }\end{array}$ \\
\hline - & $\begin{array}{l}\text { Carcinoma with liver } \\
\text { metastases }\end{array}$ & $7 \cdot 9$ & 80 & Normal & Died: hypokaleamia \\
\hline$\overline{\text { Achlorhydria }}$ & $\begin{array}{l}\text { Adenoma } \\
\text { Carcinoma with metastases }\end{array}$ & $\overline{5-6 \cdot 1}$ & $\overline{270}$ & Normal & $\begin{array}{l}\text { Remission } \\
\text { Died: carcinomatosis }\end{array}$ \\
\hline $\begin{array}{l}\text { Achlorhydria } \\
\text { Normal } \\
\text { Normal } \\
\text { Normal }\end{array}$ & $\begin{array}{l}\text { Carcinoma } \\
\text { Two adenomas } \\
\text { Adenomas } \\
\text { Adenoma }\end{array}$ & $\begin{array}{l}10 \cdot 1 \\
20 \text { stools } \\
7 \\
4 \cdot 6 \text { (approx) }\end{array}$ & $\frac{80}{\overline{3} 60 \text { (approx) }}$ & $\begin{array}{l}\text { Normal } \\
- \\
-\end{array}$ & $\begin{array}{l}\text { 'Cured' but died of acute pancreatitis } \\
\text { Survived } \\
\text { Survived } \\
\text { Died before operation }\end{array}$ \\
\hline $\begin{array}{l}\text { Achlorhydria } \\
\text { Achlorhydria }\end{array}$ & $\begin{array}{l}\text { Carcinoma } \\
\text { Adenoma }\end{array}$ & $\begin{array}{l}6 \\
10 \cdot 5\end{array}$ & $\begin{array}{l}345 \\
194\end{array}$ & Diabetic & $\begin{array}{l}\text { Survived } \\
\text { Survived }\end{array}$ \\
\hline Normal & Adenoma & 10 & 340 & Diabetic & Survived \\
\hline $\begin{array}{l}\text { Normal } \\
\text { Achlorhydria }\end{array}$ & $\begin{array}{l}\text { Carcinoma } \\
\text { Carcinoma }\end{array}$ & $\overline{5 \cdot 5}$ & $\frac{92}{-}$ & $\begin{array}{l}\text { Impaired GTT } \\
\text { Normal GTT }\end{array}$ & $\begin{array}{l}\text { Died: metastases } \\
\text { Survived }\end{array}$ \\
\hline $\begin{array}{l}\text { Normal } \\
\text { Hypochlorhydria } \\
\text { Achlorhydria }\end{array}$ & $\begin{array}{l}\text { Adenoma } \\
\text { Hyperplasia } \\
\text { Multiple adenomas and } \\
\text { islet hyperplasia }\end{array}$ & $\begin{array}{l}10 \cdot 7 \\
2 \\
2 \text { (average) }\end{array}$ & $\begin{array}{l}340 \\
144 \\
200\end{array}$ & $\begin{array}{l}\text { Diabetic } \\
\text { Normal }\end{array}$ & $\begin{array}{l}\text { Survived } \\
\text { Survived } \\
\text { Survived }\end{array}$ \\
\hline $\begin{array}{l}\text { Achlorhydria } \\
\text { Normal }\end{array}$ & $\begin{array}{l}\text { Carcinoma } \\
\text { Carcinoma and hyperplasia }\end{array}$ & $\begin{array}{l}3 \cdot 2 \text { (average) } \\
9 \cdot 2\end{array}$ & $\begin{array}{r}100 \\
453\end{array}$ & $\begin{array}{l}\text { Diabetic } \\
\text { Normal }\end{array}$ & $\begin{array}{l}\text { Died: liver metastases } \\
\text { Died: liver metastases }\end{array}$ \\
\hline
\end{tabular}


Erickson, 1944). It seems clear that water traverses the mucosa in company with sodium, though in proportionally greater amounts (Scholer and Code, 1954). Whilst exsorption ${ }^{1}$ of sodium is independent of the intraluminal concentration, the insorption ${ }^{1}$ of sodium is an active energyrequiring process (Fisher, 1955) which is blocked by enzyme inhibitors (Gilman and Koelle, 1960) and does not require an osmotic gradient (Visscher et al, 1944). Small-intestinal juice collected from a fistula has a $p \mathrm{H}$ between 6.9 and 8.6 (Schiffrin and Masset, 1939). The data of de Beer, Johnston, and Wilson (1935) show that the concentrations of $\mathrm{Cl}$ and $\mathrm{HCO}_{3}$ tend to vary reciprocally and the total cation content is approximately constant (Code, 1960). Reciprocity between the sodium and potassium content of diarrhoeal fluid was shown in the case of Hindle et al (1964) as well as in the present patient (Fig. 2). It is also a feature of other intestinal conditions associated with diarrhoea, such as ulcerative colitis (Lubran and McAllen, 1951), villous adenocarcinoma of the rectum (Shamblin, Huff, Waugh, and Moertel, 1962), long-established iseostomies (Gallagher, Harrison, and Skyring, 1963), and cholera (Watten, Morgan, Songkhla, Vanikiati, and Phillips, 1959).

Other means by which the clinical and pathological picture could be produced include increased transudation by development of greater permeability of gut or blood vessel wall, or reduced reabsorption of electrolytes and water. Both of these suggest an inhibitory or toxic effect on the bowel mucosa. As insorption of water is a passive process of considerable volume in the normal (Visscher et al, 1944), it is difficult to see how this could be increased without widespread mucosal damage. This does not occur morphologically and one cannot reconcile the rapid recovery of bowel function after removal of the tumour in some cases (Chears et al, 1960; Murray et al, 1961; Brown and Crile, 1964) with mucosal damage of any degree. It is possible to explain the diarrhoea by a defect of insorption occurring in the small bowel. This is the mechanism whereby diarrhoea is caused in dogs with niacin deficiency (Nelson, Code, and Brown, 1962). Such a defect might occur in cholera, a disease with a strikingly similar clinical picture, as a result of toxic interference with enzyme systems concerned with active insorption of sodium, whilst exsorption of fluid and electrolytes remains unimpaired.

In cholera the faecal concentration of sodium is generally higher and when the volume of faeces exceeds 3 litres in 24 hours it approaches that of the plasma. Intestinal transit time decreases as the

${ }^{1}$ Code (1960) proposed a nomenclature to avoid the confusion occasioned by such words as influx and efflux when used in connection with the gastrointestinal tract. He suggested that 'sorption' indicate the total bidirectional flow process, 'insorption' the passage from gut lumen to blood stream, 'exsorption' the passage from blood stream to gut lumen, 'absorption' where insorption exceeds exsorption, and 'enterosorption' where exsorption exceeds insorption. The last two processes constitute net rates of flow.

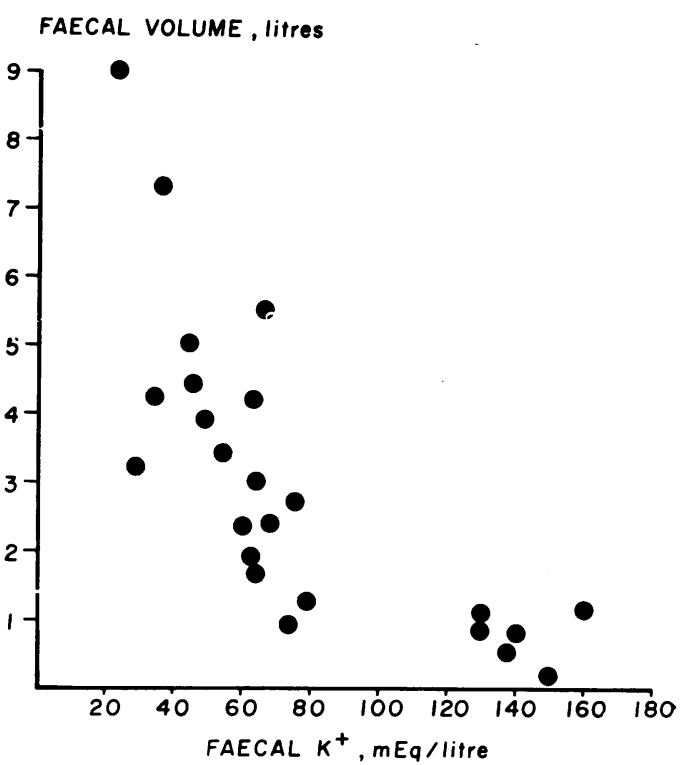

Fig. 3 Relationship of stool volume to its potassium concentration.

volume of faecal fluid increases and this contributes to an unknown degree to the increase in sodium concentration. Water and salt loading cause corresponding changes in faecal electrolytes in cholera (Watten et al, 1959) and in islet cell watery diarrhoea (Hindle et al, 1964) and it is necessary to take this into account in replacement therapy.

In contrast to sodium, as daily faecal volumes increase, the potassium concentration decreases (Fig. 3), and this is a finding common to cholera (Watten et al, 1959).

In some patients with this syndrome it has been observed that corticosteroids reduce the diarrhoeal volume (Priest and Alexander, 1957; Chears et al, 1960; Hindle et al, 1964; Marks et al, 1967), and although it was so in this patient, at certain times there was concurrent antibiotic therapy and the demonstration of a 'blind loop'. The presence of metastatic tumour tissue at necropsy showed that production of a diarrhoeainducing agent was possible throughout the illness, and therefore the later success of prednisolone and ACTH in abolishing fluid stools was a direct antagonistic action. Even then the beneficial effect may have been due to the non-specific corticosteroid effect of promoting absorption of sodium and water (Smiddy, Smith, Gregory, and Goligher, 1960) and we noted a reduction of the $\mathrm{Na} / \mathrm{K}$ ratio whilst the patient was receiving steroids. Parkins (1961) and Hindle et al (1964) claim that the effect on diarrhoea in this disease is not due to mineralocorticoid action. That there is a minimal dose of steroid necessary to suppress diarrhoea has been shown in a review of the literature by Marks et al (1967) and we found we had to exceed this minimum dose of $15-20 \mathrm{mg}$ of 
prednisolone or equivalent ACTH dosage by considerable amounts during relapses of diarrhoea thus producing the complications that follow the long-term use of such high doses. We did not see the commonest reported complication, gastrointestinal bleeding (Priest and Alexander, 1957; Chears et al, 1960; Telling and Smiddy, 1961).

How then does the diarrhoea in this syndrome differ from that of other diseases where severe potassium depletion is not a sequela? It is, we believe, due to the almost unique feature of watery stools passed unremittingly, or for long periods, over a number of years. Only in cholera is the stool similar in appearance and contains so little visible faecal matter, and in that disease the diarrhoea is too brief to allow potassium depletion to be an important feature. There is little to suggest in our studies that this patient's colon behaved other than normally in its handling of fluid and electrolytes. Shields and Miles (1965) have shown that the human colon, whilst possessing considerable reserve capacity, has a limit to the extent to which it can compensate for loss of absorptive function of the small intestine in respect of sodium and water. Further, they conclude that if, due to some disorder of the small intestine function, increased quantities of fluid pass over the colonic mucosa, increased amounts of potassium will appear in the bowel lumen. Thus the syndrome of watery diarrhoea and hypokalaemia in these patients could be explained by some mechanism which interfered with the absorption of sodium, and pari passu, water by the small intestine. Although this could be a toxic substance, consideration of the histology and other related syndromes associated with non-beta cell islet tumours makes a circulating hormone more likely. It has now been shown that this hormone is secretin, or a hormone with very similar action. Secretin is not known to have a direct action on the small intestine and its function, and we consider that further research in this field would yield important evidence about the mechanism of production of watery diarrhoea in these patients and perhaps to its control.

We gratefully acknowledge the help given by Dr Avery Jones at an early stage in the patient's illness, the surgical experience and care of $\mathbf{M r}$ John Stephen and Mr Rodney Smith during the pancreatic operations, to Dr R. A. Parker for the histological examination, and to the innumerable doctors, nurses, and technicians who were involved in her care and investigations.

We are particularly grateful to Dr E. A. Nieman, the referring consultant, and to $\mathrm{Dr}$ H. M. Lipman, the patient's general practitioner, for their help and interest throughout her illness.

\section{References}

Beer, C. J. de, Johnston, C. G., and Wilson, D. W. (1935). The composition of intestinal secretions. J. biol. Chem., 108, 113-120.
Brown, C. H., and Crile, G., Jr. (1964). Pancreatic adenoma with intractable diarrhea, hypokalemia and hypercalcemia. J. Amer. med. Ass., 190, 30-34.

Charles, B., and Cochrane, W. A. (1960). Islet cell tumour of the pancreas with chronic diarrhoea and hypokalaemia. Canad. med. Ass. J., 82, 579-586.

Chears, W. C., Jr, Thompson, J. E., Hutcheson, J. B., and Patterson, C. O. (1960). Pancreatic islet cell tumour with severe diarrhea. Amer. J. Med., 29, 529-533.

Code, C. F. (1960). The semantics of the process of absorption. Perspect. Biol. Med., 3, 560-562.

Davis, C. E., Jr., Smith, P., Jr., and Davalos, X. S. (1962). Ulcerogenic tumour of the pancreas. Ann. Surg., 155, 669-680.

Deleu, J., Tytgat, H., and Goidsenhoven, G. E. van (1964). Diarrhea associated with pancreatic islet-cell tumors. Amer. J. dig. Dis., 9, 97-108.

Edmeads, J. G., Matthews, R. E., McPhedran, N. T., and Ezrin C. (1962). Diarrhoea caused by pancreatic islet-cell tumours. Canad. med. Ass. J., 86, 847-851.

Ellison, E. H., and Wilson, S. D. (1964). The Zollinger-Ellison Syndrome: Re-appraisal and evaluation of 260 registered cases. Ann. Surg., 160, 512-530.

Espiner, E. A., and Beaven, D. W. (1962). Non-specific islet-cell tumours of the pancreas with diarrhoea. Quart. J. Med., $31,447-471$.

Fisher, R. B. (1955). The absorption of water and some small solute molecules from the isolated small intestine of the rat. J. Physiol. (Lond.), 130, 655-664.

Fourman, P., and McCance, R. A. (1955). Tetany complicating the treatment of potassium deficiency in renal acidosis. Lancet, 1, 329-331.

Gallagher, N. D., Harrison, D. D., and Skyring, A. P. (1963). Fluid and electrolyte disturbances in patients with longestablished ileostomies. Gut, 3, 219-223.

Gilman, A., and Koelle, E. S. (1960). Substrate requirements for ion transport by rat intestine studied in vitro. Amer. $J$. Physiol., 199, 1025-1029.

Glober, G. (1968). Case presentation. In Longmire, W. P. et al. The UCLA Interdepartmental Conference. Islet cell tumours of the pancreas. Ann. intern. Med., 68, 203-221.

Gordon, B. S., and Olivetti, R. G. (1947). Carcinoma of the islets of Langerhans; review of the literature and report of two cases. Gastroenterology, 9, 409-424.

Goulon, M., Mercier, J. N., Reilly, J., and Laporte, A. (1960). Carcinome Langehansien responsable d'hypersecretion gastrique acide, de diarrhée chronique, d'hypokaliémie sévère avec paralysies et d'hypoglycémie. Sem. Hôp. Paris, 36, 812-824.

Goulon, M., Rapin, M., Charleux, H., Baguet, J.-C., Kuntziger, H., Nouailhat, F., Bardis, A., and Bretaue, M. (1966) Diarrhée aqueuse et hypokaliémie associées à une tumeur Langer-Lansienne non insulino-sécrétante. Bull. Soc. méd. Hóp., Paris, 117, 623-646.

Gregory, R. A. (1962). Secretory Mechanism of the Gastrointestinal Tract, pp. 213-239. Arnold, London.

Gregory, R. A., and Tracy, H. J. (1964). Constitution and properties of two gastrins extracted from hog antral mucosa. Gut, 5, 103-117.

Gregory, R. A., Tracy, H. J., French, J. M., and Sircus, W. (1960). Extraction of a gastrin-like substance from a pancreatic tumour in a case of Zollinger-Ellison Syndrome. Lancet, 1, 1045-1048.

Hess, W. (1968). Diarrhoën mit Hypokaliämie, Prädiabetes und Subacidität, ein neues Syndrom bei Úberfunktion des Inselapparates. Helv. chir. Acta., 35, 87-90.

Hindle, W., McBrien, D. J., and Creamer, B. (1964). Watery diarrhoea and an islet-cell tumour. Gut, 5, 359-362.

Knappe, G. von, Flemming, F., Stobbe, H., and Wendt, F. (1966). Pankreasinsellzelladenom mit der Trias Diarrhoe Hypokaliämie und Hyperglykämie. Dtsch. med. Wschr., 91, 1224-1228.

Kofstad, J., Frøyshov, I., Gjone, E., and Blix, S. (1967). Pancreatic tumour with intractable watery diarrhea, hypokalemia and hypercalcemia. Electrolyte balance studies. Scand. J. Gastroent., 2, 246-250.

Longmire, W. P. (1964). In discussion to Ellison and Wilson (1964).

Lubran, M., and McAllen, P. M. (1951). Potassium deficiency in ulcerative colitis. Quart. J. Med., 20, 221-232.

Marks, I. N., Bank, S., and Louw, J. H. (1967). Islet cell tumor of the pancreas with reversible watery diarrhea and achlorhydria. Gastroenterology, 52, 695-708.

Matsumoto, K. K., Peter, J. B., Schultze, R. G., Hakim, A. A., and Franck, P. T. (1966). Watery diarrhea and hypokalemia associated with pancreatic islet cell adenoma, Gastroenterology, 50, 231-242.

Martini, G. A., Strohmeyer, G., Haug, P., and Gusek, W. (1964). Inselzelladenom des Pankreas mit urtikariellem Exanthem. 
Durchfällen sowie Kalium-und Eiweissverlust über den Darm. Dtsch. med. Wschr., 89, 313-322.

Moldawer, M. P., Nardi, G. L., and Raker, J. W (1954). Concomitance of multiple adenomas of the parathyroids and pancreatic islets with tumors of the pituitary. A syndrome with familial incidence. Amer. J. med. Sci., 228, 190-206.

Morrison, A. B., Rawson, A. J., and Fitts, W. T., Jr. (1962). The syndrome of refractory watery diarrhea and hypokalemia in patients with non-insulin secreting islet cell tumor. Amer. J. Med., 32, 119-127.

Murray, J. S., Paton, R. R., and Pope, C. E. II. (1961). Pancreatic tumour associated with flushing and diarrhoea. New Engl. J. Med., 264, 436-439.

Nelson, R. A., Code, C. F., and Brown, A. L. (1962). Sorption of water and electrolytes and mucosal structure in niacin deficiency. Gastroenterology, 42, 26-35.

Pabst, K., Kümmerle, F., Hennekedser, H. H., and Mappes, G. (1969). Beitrag zum Krankheitsbild des Verner-MorrisonSyndroms. Dtsch. med. Wschr., 94, 9-13.

Parkins, R. A. (1961). Severe watery diarrhoea and potassium depletion associated with an islet cell tumour of pancreas. Brit. med. J., 2, 356-357.

Priest, W. M., and Alexander, M. K. (1957). Islet-cell tumour of the pancreas with peptic ulceration, diarrhoea and hypokalaemia. Lancet, 2, 1145-1147.

Robertson, J. I. S., Peart, W. S., and Andrews, T. M. (1962). The mechanism of facial flushes in the carcinoid syndrome. Quart. J. Med., 31, 103-122.

Schiffrin, M. J., and Nasset, E. S. (1939). The response of jejunum and ileum to food and enterocrinin. Amer. J. Physiol., 128, 70-80.

Scholer, J. F., and Code, C. F. (1954). Rate of absorption of water from stomach and small bowel of human beings. Gastroenterology, 27, 565-577.

Schwartz, W. B., and Relman, A. S. (1953). Metabolic and renal studies in chronic potassium depletion resulting from overuse of laxatives. J. clin. Invest., 32, 258-271.

Shamblin, J. R., Huff, J. F., Waugh, J. M., and Moertel, C. G. (1962). Villous adenocarcinoma of the colon with pro- nounced electrolyte disturbance. Amer. Surg., 156, 318-326. Shields, R., and Miles, J. B. (1965). Absorption and secretion in the large intestine. Postgrad. med. J., 41, 435-439.

Smiddy, F. G., Smith, I. B., Gregory, S. D., and Goligher, J. C. (1960). Faecal loss of fluid, electrolytes and nitrogen in colitis before and after ileostomy. Lancet, 1, 14-19.

Telling, M., and Smiddy, F. G. (1961). Islet tumours of the pancreas with intractable diarrhoea. Gut, 2, 12-17.

Thaysen, J. H. (1960). In Handbuch der experimentellen Pharmakologie, Vol. 13, pp. 483-485. Springer, Berlin.

Thompson, J. E. (1962). In discussion to Davis, Smith, and Davalos (1962).

Tompkins, R. K., Kraft, A. R., and Zollinger, R. M. (1969) Secretin-like choleresis produced by a diarrhoegenic nonbeta islet cell tumor of the pancreas. Surgery, 66, 131-137.

Verner, J. V., and Morrison, A. B. (1958). Islet cell tumor and a syndrome of refractory watery diarrhea and hypokalemia. Amer.J. Med., 25, 374-380.

Visscher, M. B., Varco, R. H., Carr, C. W., Dean, R. B., and Erickson, D. (1944). Sodium ion movement between the intestinal lumen and the blood. Amer. J. Physiol., 141, 488-505.

Watten, R. H., Morgan, F. M., Songkhla, Y. N., Vanikiati, B., and Phillips, R. A. (1959). Water and electrolyte studies in cholera. J. clin. Invest., 38, 1879-1889.

Weber, J. M., Lewis, S., and Heasley, K. H. (1959). Observations on the small bowel pattern associated with the ZollingerEllison Syndrome. Amer. J. Roentgenol., 82, 973-977.

Williams, E. D., and Sandler, M. (1963). The classification of carcinoid tumours. Lancet, 1, 238-239.

Wormsley, K. G. (1968). Response to secretin in man. Gastroenterology, 54, 197-209.

Zollinger, R. M., and Ellison, E. H. (1955). Primary peptic ulceration of the jejunum associated with islet-cell tumours of the pancreas. Ann. Surg., 142, 709-728.

Zollinger, R. M., Tompkins, R. K., Amerson, J. R., Endahl, G. L., Kraft, A. R., and Moore, F. T. (1968). Identification of the diarrhoegenic hormone associated with non-beta islet cell tumours of the pancreas. Ann. Surg., 168, 502-521. 